\title{
Phytoprotection
}

\section{A note on the use of microbial insecticides for the control of tomato hornworms on flue-cured tobacco}

\section{H.H. Cheng et J.J. Hanlon}

Volume 71, numéro 2, 1990

URI : https://id.erudit.org/iderudit/705989ar

DOI : https://doi.org/10.7202/705989ar

Aller au sommaire du numéro

Éditeur(s)

Société de protection des plantes du Québec (SPPQ)l

ISSN

0031-9511 (imprimé)

1710-1603 (numérique)

Découvrir la revue

Citer cet article

Cheng, H. \& Hanlon, J. (1990). A note on the use of microbial insecticides for the control of tomato hornworms on flue-cured tobacco. Phytoprotection, 71(2), 101-103. https://doi.org/10.7202/705989ar
Résumé de l'article

Deux formulations du Bacillus thuringiensis, la Bactospéine-A et le Thuricide-HPC, ont été appliquées sur des plantes de tabac (Nicotiana tabacum) étêtées afin d'évaluer leur efficacité envers le sphinx de la tomate (Manduca quinquemaculata) en laboratoire et au champ. Les deux insecticides ont procuré une répression complète des sphinx de la tomate, peu importe les doses appliquées. Toutes les larves se sont nourries légèrement ou modérément sur les feuilles traitées au cours de la première journée suivant le traitement mais par la suite, les larves sont demeurées inactives sur les feuilles traitées jusqu'à leur mort. Il y a peu d'évidence d'une alimentation subséquente quand les feuilles ont été examinées. Ces insecticides microbiens n'ont eu aucun effet néfaste sur le parasite du sphinx de la tomate, Cotesia congragata, et aucune phytotoxicité n'a été observée. 


\title{
A note on the use of microbial insecticides for the control of tomato hornworms on flue-cured tobacco
}

\author{
H. H. Cheng ${ }^{1}$ and J. J. Hanlon \\ Research Station, Agriculture Canada, Delhi, \\ Ontario, Canada N4B 2W9. Contribution No. 211 \\ 1. Deceased
}

(Received 1989-04-25; accepted 1990-01-29)

Two formulations of Bacillus thuringiensis, Bactospeine-A and Thuricide-HPC, were applied on tobacco plants after topping to evaluate their effectiveness against tomato hornworm (Manduca quinquemaculata) in the laboratory and field. Both materials, regardless of the rates applied, gave complete control of the tomato hornworms. All the larvae fed slightly or moderately on the treated leaves during the first day after treatment, but thereafter, the larvae remained inactive on the treated leaves until death. There was little evidence of further feeding when the leaves were examined. The microbial insecticides had no detrimental effect on the beneficial insect parasite, Cotesia congragata, and no phytotoxicity was observed.

Cheng, H. H., and J. J. Hanlon. 1990. A note on the use of microbial insecticides for the control of tomato hornworms on flue-cured tobacco. PHYTOPROTECTION 71 : 101-103.

Deux formulations du Bacillus thuringiensis, la Bactospéine-A et le Thuricide-HPC, ont été appliquées sur des plantes de tabac (Nicotiana tabacum) étêtées afin d'évaluer leur efficacité envers le sphinx de la tomate (Manduca quinquemaculata) en laboratoire et au champ. Les deux insecticides ont procuré une répression complète des sphinx de la tomate, peu importe les doses appliquées. Toutes les larves se sont nourries légèrement ou modérément sur les feuilles traitées au cours de la première journée suivant le traitement mais par la suite, les larves sont demeurées inactives sur les feuilles traitées jusqu'à leur mort. Il y a peu d'évidence d'une alimentation subséquente quand les feuilles ont été examinées. Ces insecticides microbiens n'ont eu aucun effet néfaste sur le parasite du sphinx de la tomate, Cotesia congragata, et aucune phytotoxicité n'a été observée.

Tomato hornworm, Manduca quinquemaculata (Haw.), is a major pest on many agriculturally important crops in North America, such as tobacco (Nicotiana tabacum L.), tomato (Lycopersicon esculentum Mill.), potato (Solanum tuberosum L.), pepper (Capsicum annuum L.), and related plants (Swan and Papp 1972). In Ontario, the tomato hornworm is found on tobacco during July and August (Cheng 1977b, 1982). A moderate to heavy infestation of the tomato hornworm in tobacco can significantly reduce crop yield (Cheng 1977a).

The need to find environmentally safe insecticides particularly materials that are effective against species resistant to chemical pesticides has stimulated interest in alternative insecticides. Bactospeine-A containing Bacillus thuringiensis var. kurstaki (Berliner) has been demonstrated to be a promising alternative to chemical insecticides for control of some lepidopterous insect pests on field and vegetable crops (Jackson 1986; Moar et al. 1986). Currently, two formulations of $B$. thuringiensis, Dipel and Thuricide-HPC, are registered in Canada for use on tobacco to control the tomato hornworm (Anonymous 1988). A third formulation, Bactospeine- $\mathrm{A}$, is registered for use on vegetable crops (Anonymous 1986), but it has not been approved for use to protect tobacco against the tomato hornworm. Investigations reported here were conducted to compare the effectiveness of Bactospeine-A with a registered microbial insecticide as part of a continuing program in controlling the tomato hornworm on tobacco.

Experiments were carried out at Agriculture Canada Research Station, Delhi, Ontario, during 1985 and 1986 on fluecured tobacco plants cv. Candel. Normal cultural practices were followed, and recommended cutworm and nematode control measures were used.

Plots were $6.10 \mathrm{~m}$ long, $1.07 \mathrm{~m}$ wide, and arranged in a randomized complete 
Table 1. Effects of microbial insecticides applied to field-grown tobacco against tomato hornworms - 2-year average

\begin{tabular}{|c|c|c|c|c|c|c|c|}
\hline \multirow[b]{2}{*}{ Treatment } & \multirow{2}{*}{$\begin{array}{l}\text { Rate } \\
(\mathrm{L} / \mathrm{ha})\end{array}$} & \multicolumn{4}{|c|}{$\begin{array}{l}\text { Percentage of cumulative mortality } \\
\text { days after treatment }\end{array}$} & \multirow{2}{*}{$\begin{array}{c}\text { Percentage of } \\
\text { larvae } \\
\text { parasitized }\end{array}$} & \multirow{2}{*}{$\begin{array}{l}\text { Number } \\
\text { of leaves } \\
\text { damaged }\end{array}$} \\
\hline & & 1 & 2 & 4 & 5 & & \\
\hline \multicolumn{8}{|l|}{ Laboratory test } \\
\hline Bactospeine-A & $\begin{array}{l}1.0 \\
2.0\end{array}$ & $\begin{aligned} 0 \mathrm{~b}^{\S} \\
12 \mathrm{a}\end{aligned}$ & $\begin{array}{l}32 \mathrm{bc} \\
65 \mathrm{a}\end{array}$ & $\begin{array}{r}98 \mathrm{a} \\
100 \mathrm{a}\end{array}$ & $\begin{array}{l}100 \mathrm{a} \\
100 \mathrm{a}\end{array}$ & $\begin{array}{l}18^{\dagger} \\
12\end{array}$ & $\begin{array}{l}0.16 \mathrm{a} \\
0.18 \mathrm{a}\end{array}$ \\
\hline Thuricide-HPC & $\begin{array}{l}1.0 \\
1.5\end{array}$ & $\begin{array}{l}0 \mathrm{~b} \\
0 \mathrm{~b}\end{array}$ & $\begin{array}{l}25 \mathrm{c} \\
48 \mathrm{ab}\end{array}$ & $\begin{array}{r}95 \mathrm{a} \\
100 \mathrm{a}\end{array}$ & $\begin{array}{l}100 \mathrm{a} \\
100 \mathrm{a}\end{array}$ & $\begin{array}{l}17 \\
16\end{array}$ & $\begin{array}{l}0.21 \mathrm{a} \\
0.15 \mathrm{a}\end{array}$ \\
\hline Untreated Check & - & $0 \mathrm{~b}$ & $5 \mathrm{~d}$ & $17 \mathrm{~b}$ & $20 \mathrm{~b}$ & 20 & $1.86 \mathrm{~b}$ \\
\hline \multicolumn{8}{|l|}{ Field test } \\
\hline Bartospeine-A & $\begin{array}{l}1.0 \\
2.0\end{array}$ & $\begin{array}{l}0 \\
0\end{array}$ & $\begin{array}{l}23 \mathrm{~b} \\
48 \mathrm{a}\end{array}$ & $\begin{array}{l}100 \mathrm{a} \\
100 \mathrm{a}\end{array}$ & & $\begin{array}{l}13 \\
17\end{array}$ & $\begin{array}{l}0.22 \mathrm{a} \\
0.15 \mathrm{a}\end{array}$ \\
\hline Thuricide-HPC & $\begin{array}{l}1.0 \\
1.5\end{array}$ & $\begin{array}{l}0 \\
0\end{array}$ & $\begin{array}{l}20 \mathrm{~b} \\
35 \mathrm{ab}\end{array}$ & $\begin{array}{r}98 \mathrm{a} \\
100 \mathrm{a}\end{array}$ & & $\begin{array}{l}18 \\
15\end{array}$ & $\begin{array}{l}0.25 \mathrm{a} \\
0.17 \mathrm{a}\end{array}$ \\
\hline Untreated Check & - & 0 & $2 \mathrm{c}$ & $16 \mathrm{~b}$ & & 16 & $2.26 \mathrm{~b}$ \\
\hline
\end{tabular}

$\S \quad$ Means within vertical columns for each test, followed by the same letter are not significantly different at the $5 \%$ level as determined by Duncan's multiple range test.

$\dagger F$ test not significant for these data.

block design with two replications of five treatments (Table 1). Each plot, separated by a guard row, was a single row of 10 fullgrown topped tobacco plants. Two microbial insecticides, Bactospeine-A $\left(9.68 \times 10^{9} \mathrm{IU} / \mathrm{L}\right)$ and Thuricide-HPC $\left(4.2 \times 10^{9} \mathrm{IU} / \mathrm{L}\right)$ were evaluated with the latter acting as a standard insecticide. The materials were applied uniformly to the tobacco leaves using a Knapsack sprayer with an adjustable cone type nozzle to deliver $450 \mathrm{~L}$ of solution per hectare.

Third- and fourth-instar larvae of the tomato hornworm were collected each year from tobacco plants in unsprayed fields in early August and used in the experiments. In laboratory tests, the larvae, 10 for each of the four replicates, were placed individually in $680-\mathrm{mL}$ wide mouth jars. Two hours after application of the insecticides, tobacco leaves were collected at random from each plant and placed in the jars with the larvae. The leaves were replaced as required by fresh untreated leaves. Rearing was conducted at room temperature $\left(22^{\circ}-23^{\circ} \mathrm{C}\right)$ under 16-h photoperiod and 55 to $60 \% \mathrm{RH}$. In field tests, one larva per plant was placed on the upper third of the treated plants approximately $3 \mathrm{~h}$ after treatment.

Larval mortalities and foliar damage by the larvae were assessed daily for 5 days for the laboratory tests and 4 days for the field tests. Larvae parasitized by insect parasites were recorded. The amount of folliage eaten from each leaf by the larvae was recorded in units of $1 / 8,1 / 4,3 / 8$, or $1 / 2$ leaf. Injury of less than $1 / 8$ of the leaf was recorded as $1 / 8$, and so forth. By summing the recorded fractions, an estimate of the number of leaves destroyed was obtained. Abbott's formula (1925) was used to correct for the mortality occurring in the untreated check. Before analysis of variance, data were transformed into angular units (LeClerg et al. 1962) and Duncan's multiple range test was used to separate treatment means. Means presented in Table 1 are in the original units.

In the laboratory or field tests, mortality of the tomato hornworm larvae fed with leaves treated with the microbial insecticides was effective and consistent within each treatment in the two years of experiments. Since there were no significant differences between years of each experiment, the results for each treatment were pooled and are presented in Table 1.

Laboratory tests. All the larvae fed on the leaves treated with Bactospeine-A or Thuricide-HPC, and the area of leaf consumption varied with the larval size. Some of the larvae fed a little on the second day but not afterward. Larvae on the untreated leaves consumed significantly $(P \leq 0.05)$ 
more leaf tissue than those on the treated leaves (Table 1), so that the leaves in the untreated check had to be replaced daily by fresh untreated leaves.

One day after treatment, larvae feeding on Bactospeine-A $(2.0 \mathrm{~L} / \mathrm{ha})$ treated leaves showed some mortality. All other larvae were inactive. Two days after treatment, the tomato hornworm larvae feeding on treated leaves showed significantly greater $(P \leq 0.05)$ mortality when compared with the untreated check, and the high rate of each insecticide was more toxic than the low rate of the same insecticide. Percent larval mortality increased over time and complete mortality was observed 5 days after treatments.

Bactospeine-A and Thuricide-HPC appeared to have no detrimental effect on beneficial insects (Table 1). Three to five days after the tomato hornworm larvae were reared in the laboratory, adults of Cotesia congragata (Say), a very common parasite of the tomato hornworm in the tobacco growing areas of Ontario (Cheng 1973) emerged from these larvae. Low larval mortality in the untreated check was caused by C. congragata.

Field tests. The tomato hornworm larvae that were placed on tobacco leaves in the treated plots were killed within 4 days after treatment with the exception of those in plots treated with Thuricide-HPC at $1.0 \mathrm{~L} /$ ha (Table 1). Larval mortality did not differ significantly among the insecticide treatments, and the results from the field tests were similar to the laboratory tests. Leaf consumption did not differ significantly among the insecticide-treated plots, but it was significantly different $(P \leq 0.05)$ when compared with the untreated check (Table 1). Plants in the untreated plots were severely damaged. No visible phytotoxicity was observed on the plants treated with the microbial insecticides.

Since both microbial insecticides were effective in controlling the tomato hornworm larvae with no detrimental influence on the development of the parasitic $C$. congragata in the hornworm larvae, Bactospeine-A can therefore be considered a suitable alternative to Thuricide-HPC for control of tomato hornworms on tobacco.

Abbott, W.S. 1925. A method of computing the effectiveness of an insecticide. J. Econ. Entomol. 18: 265-267.

Anonymous. 1986. Vegetable production recommendations. Ont. Min. Agric. Food Publ. 363, 71 pp.

Anonymous. 1988. Tobacco production recommendations. Ont. Min. Agric. Food Publ. 298, 40 pp.

Cheng, H.H. 1973. Microplot test using microbial and chemical insecticides for control of tomato hornworms on tobacco in Ontario. The Lighter 43: 10-13.

Cheng, H.H. 1977a. Flue-cured tobacco losses caused by the tomato hornworm, Manduca quinquemaculata (Lepidoptera: Sphingidae), at various infestation levels in Ontario. Can. Entomol. 109: 1091-1095.

Cheng, H.H. 1977b. Insecticides and sucker control chemicals: compatibility and effects on green peach aphid, tomato hornworm and suckers on flue-cured tobacco in Ontario. Tob. Sci. 21: 108-111.

Cheng, H.H. 1982. Seasonal abundance of tomato hornworm and other sphingids in the flue-cured tobacco district of southwestern Ontario, 1968 to 1981. Tob. Sci. 26: 153-156.

Jackson, D.M. 1986. Control of tobacco insect pests with Bacillus thuringiensis var. kurstaki formulations. Insecticide Acaricide Tests 11: 360-361.

LeClerg, E.L., W.H. Leonard, and A.G. Clark. 1962. Field plot technique, 2nd ed. Burgess Publ. Co., Minneapolis, 373 pp.

Moar, W.J., W.L.A. Osbrink, and J.T. Trumble. 1986. Potentiation of Bacillus thuringiensis var. kurstaki with thuringiensin on beet armyworm (Lepidoptera: Noctuidae). J. Econ. Entomol. 79: 1443-1446.

Swan, L.A., and C.S. Papp. 1972. The common insects of North America. Harper and Row, New York, $750 \mathrm{pp}$. 